\title{
PHYSICOCHEMICAL CHARACTERISTIC OF FERMENTED GOAT MILK ADDED WITH DIFFERENT STARTERS LACTIC ACID BACTERIA
}

\author{
Anif Mukaromah Wati ${ }^{1,2)}$, Mei-Jen Lin ${ }^{4)}$, Lilik Eka Radiati ${ }^{3)}$ \\ 1) Student of Master Post Graduate, Faculty of Animal Science, Brawijaya University, Veteran Street, Malang, \\ East Java, Indonesia. 65145 \\ 2) Student of Double Degree Department of Animal Science, National Pingtung University of Science and \\ Technology, Taiwan \\ 3) Faculty of Animal Science, Brawijaya University, Veteran Street, Malang, East Java, Indonesia. 65145 \\ ${ }^{4)}$ Department of Animal Science, National Pingtung University of Science and Technology, Taiwan \\ Email : anifmukaromahwati@gmail.com
}

Diterima 4 Maret 2018; diterima pasca revisi 27 Maret 2018

Layak diterbitkan 28 Maret 2018

\begin{abstract}
Development of traditional food including dadih to be commercial fermented milk was needed to achieve efficiency and effective of products. Dadih with natural starter needs to be changed with starters because starters can be produced commercially. This study aims to evaluate physicochemical characteristic of fermented goat milk that added with different starters Lactic Acid Bacteria (LAB) isolated from dadih. The materials used for this research were starters LAB that isolated from dadih. In this experiment, treatments were used different starters that namely starter 11, starter 21, starter 25, starter 29, and starter 41 then analized about water content, ash content, fat content, syneresis, and viscosity. The experiment was carried out with three replications. The data were analyzed by ANOVA using the basic design of Completely Randomized Design (CRD) and continued by Duncan's Multiple Range Test (DMRT) if there was a significantly different. The results showed that different starters had influence on water content, ash content, fat content, syneresis, and viscosity. It could be concluded that starters 11 and 41 were the best starter that can be applied in fermented goat milk product based on physical quality with lower syneresis and higher viscosity. But based on chemical quality, starter 11 was the best starter with lower water content and higher ash content.
\end{abstract}

Keywords : Starters LAB; dadih 


\begin{abstract}
ABSTRAK
Dadih merupakan produk susu fermentasi pengembangan makanan tradisional menjadi produk komersial yang efisien dan efektif. Dadih menggunakan starter natural dan saat ini starter yang digunakan diisolasi ditingkatkan untuk diproduksi secara komersial. Penelitian ini bertujuan untuk mengevaluasi Lactic Acid Bacteria (LAB) yang diisolasi dari dadih. Bahan yang digunakan untuk penelitian ini adalah LAB yang diisolasi dari dadih. Dalam percobaan ini menggunakan, starter 21, starter 25, starter 29, dan starter 41 kemudian dianalisa tentang kadar air, kadar abu, kadar lemak, sineresis, dan viskositas. Percobaan dilakukan dengan tiga ulangan. Data dianalisis menggunakan analisi ragam (Anova) dengan Uji Jarak Berganda Duncan (DMRT) jika ada perbedaan yang. Hasil penelitian menunjukkan bahwa starter yang diisolasi dari dadih yang berbeda memberikan pengaruh terhadap kadar air, kadar abu, kadar lemak, sineresis, dan viskositas. Dapat disimpulkan bahwa starter 11 dan 41 adalah starter terbaik yang dapat diterapkan dalam sineresis berbasis susu kambing fermentasi dan memiliki viskositas yang lebih tinggi. Namun berdasarkan kualitas kimia, starter 11 adalah starter terbaik dengan kandungan air yang lebih rendah dan kandungan abu yang lebih tinggi.
\end{abstract}

Kata kunci: Bakteri asam laktat; dadih

\section{INTRODUCTION}

Dadih or dadiah, a traditional food from West Sumatra, Indonesia, is made from buffalo milk, then poured and fermented in bamboo tubes. Syukur et al. (2016) stated that the problem of dadih is still made with traditional way. In West Sumatera, dadih is not using starter and did't have any standard for nutrient and the making of dadih. The other problem of dadih that using traditional way (natural fermentation) can give variations in the characteristics, quality, and acceptability of dadih. Traditional way of dadih with natural starter needs to be changed with starter culture as starter culture make dadih more stable than using bamboo tube. Starters can use from LAB

*Corresponding author:

Anif Mukaromah Wati

Email : anifmukaromahwati@gmail.com

Student of Master Post Graduate, Faculty of Animal

Science, Brawijaya University, Veteran Street,

Malang, East Java, Indonesia. 65145 as they can convert carbohydrate into lactic acid (Nuraida, 2015). The parameter of industry to using LAB is capability to convert into lactic acid of raw materials because acidification can prevent growth of undesirable microorganisms and make the product with desirable aroma, texture, and flavor (Akabanda et al., 2014). LAB utilized milk protein, then affected to enhance free amino and peptides. Moreover, LAB have market potential and claimed as probiotic because LAB are affecting to improve microbial balance in intestinal (Surono, 2003). Starters from LAB can obtain from dadih because dadih contain of LAB.

$\mathrm{LAB}$ of dadih are from raw material to make dadih that including buffalo milk, banana leaves, and bamboo tubes. Generally, LAB in

How to cite:

Wati, A.M., Lin, M.J., Radiati, L.E.. (2018).

Physicochemical Characteristic of Fermented Goat Milk

Added with Different Starters Lactic Acid Bacteria.

Jurnal Ilmu dan Teknologi Hasil Ternak, 13 (1), 54-62 
spontaneous lactic lactic acid fermentation including dadih were identified from Lactobacillus plantarum and Lactobacillus fermentum. Making dadih can use cow or goat milk because population of bufallo milk is decrease. Goat milk can be produced to ferment milk product (Yelnetty, et al., 2014). Goat milk has LAB including Lactobacillus subsp. that potential to be antifungal (Widyastuti et al., 2014). Goat milk has functional components: proteins, vitamins (such as vitamins $\mathrm{E}$ and $\mathrm{C}$ ), flavonoids, carotenoid, and antioxidant properties (Alyaqoubi et al., 2015). In a previous experiment (Elida 2002), it was made dadih with yellow bamboo (Bambusa vulgaris), betung bamboo (Dendrocalamus asper), talang bamboo (Schizoztachyum brachycladum), and gombong bamboo (Gigantochloa verticillata). Characteristic of dadih is affected by different bamboo as packaging. Taiwanhas thorny bamboo (Bambusa stenostachya Hackel) resources due to its environment which is suitable for bamboo growth. Thorny bamboo contains ash $2.66 \pm 0.02 \%$, hot water extractives $7.52 \pm 0.05 \%, 1 \% \mathrm{NaoH}$ extractives $25.62 \pm$ $0.10 \%$, alcohol-benzene extractives $75 \pm$ $0.14 \%$, lignin $25.21 \pm 0.05 \%$, holocellulose $68.53 \pm 0.11 \%$, and pentosans $17.55 \pm 0.10 \%$ (Wang and Tsai, 2015).

This study aims to evaluate physicochemical characteristic of fermented goat milk that added with different starters isolated from dadih which packaging from Taiwan bamboo .

\section{MATERIALS AND METHODS}

\section{Materials}

Experiment was conducted from March until December, 2017 in Dairy Labolatory
Department of Animal Science, National Pingtung University of Science and Technology (NPUST), Taiwan. The materials in this experiment were starters LAB and goat milk. Starters were obtained from Dairy Labolatory, Department of Animal Science, NPUST, Taiwan and goat milk was collected from dairy Alpine goat farm at Pingtung, Taiwan. Starters LAB that used in this experiment were isolated from dadih. Dadih was made with poured fresh goat milk to bamboo tube, which was special bamboo from taiwan: Bambusa stenostachya Hackel. After poured fresh goat milk to bamboo tube, bamboo tube was covered with banana leaves, and fermented in incubator $37^{\circ} \mathrm{C}$ during $30 \mathrm{~h}$. Then, dadih was isolated and identified the similar characteristic its starters with LAB. The identification was purposed to ensure the starters was from $\mathrm{LAB}$, the identification including: microscopic identification, Gram stain, catalase test, motility test, and proteolytic activity test. The characteristic of starters were rod shape, Gram stain positive, and negative motility test and catalase test, and positive proteolytic activity. Moreover, starters had ability to decrease $\mathrm{pH}$, increase TA (Titratable Acidity) and viability of LAB, and made a curd formation.

\section{Methods}

The methods of this research was experiment. Goat milk was homogenization, pasteurized at $85^{\circ} \mathrm{C}$ for $30 \mathrm{~min}$, added with $3.0 \%$ of starters, incubated at $37^{\circ} \mathrm{C}$ for $48 \mathrm{~h}$ in incubator. In this experiment, treatment was used different starters that namely starter 11 , starter 21, starter 25, starter 29, and starter 41 , then analized ash content, water content, fat content, syneresis, and viscosity. The study was conducted with three replications. The data were 
analyzed by ANOVA using the basic design of Completely Randomized Design (CRD). Perform data analysis was used Statistical Analysis System (version 9.3, SAS) and continued by Duncan's Multiple Range Test (DMRT) if there was a significantly different. Parameters observed including ash content, water content, fat content, syneresis, and viscosity. Analysis of this experiment:

1. Analysis of water content: sample $1.0 \mathrm{~g}$ was weighed and placed in oven (WTC Binder, Tuttlingen, Germany) at $105^{\circ} \mathrm{C}$ for $8 \mathrm{~h}$ (Modified from AOAC, 2000).

2. Analysis of ash content: sample $1.0 \mathrm{~g}$ was weighed and ignited with VULCAN A-550 (Ney Dental Inc (NDI), California, USA) for $12 \mathrm{~h}$ at $600^{\circ} \mathrm{C}$ (Modified from AOAC, 2000).

3. Analysis of fat content: The bag paper XT4 Filter bags (Ankom Technology, New York, USA) was dried at oven (WTC Binder, Tuttlingen, Germany) at $105^{\circ} \mathrm{C}$ for $18 \mathrm{~h}$. Sample $1.0 \mathrm{~g}$ was weighed, transffered in bag paper and sealed to avoid loss of sample. The sample was extracted wih (Ankom Extractor model XT 10, New York, USA) that already poured with 350 $\mathrm{mL}$ Petroleum benzine (Merck, Taipei, Taiwan). After extraction, samples was dried in oven at $105^{\circ} \mathrm{C}$ for $3 \mathrm{~h}$. Directly, samples was transferrred in exsicator for 15 min and redried in oven for 20 min until the weight was constant (Modified from Aji et al., 2015).

4. Anlalysis of viscosity: viscosity measurements were obtained using a Brookfield viscometer (Model DV-II+; Brookfield Engineering Labs, Inc., MA, USA) with spindle 2, rotating at $60 \mathrm{rpm}$ and setting the temperature $4^{\circ} \mathrm{C}$ (Modified from Vareltzis et al., 2015).

5. Anlalysis of syneresis: syneresis was determined by Centrifuges universal $320 \mathrm{R}$ (Sunway Scientific Corporation, New Taipei, Taiwan). Samples $20 \mathrm{~g}$ was rotated at $222 \mathrm{~g}$ for $10 \mathrm{~min}$ at $4^{\circ} \mathrm{C}$ (Modified from Nouri et al., 2011). The formula to determine syneresis used:

Clear supernatant $\times 100$

Initial weight

(Nouri et al., 2011)

\section{RESULTS AND DISCUSSION}

\section{Water content}

Different starters had significant difference $(p<0.05)$ on water content (Table 1$)$. Starter 11 had lower of water content: $90.48 \pm$ 0.33 and starter 21 had higher: $91.21 \pm 0.08$. Water content had negative correlation with ash content and fat content. Starter 11 had lower of water content while higher of ash content and fat content as part of total solid in milk. Higher of water content of starter 21 was caused by lower activity of starter 21 that effecting to lower curd formation or total solid. On the other hand, low water content on starter 11 because starter was higher to produce lactic acid, precipitated a milk protein, formed curd, and effected to decrease water content in the end of fermentation. Lawal and Adedeji (2013) stated that water content on fermented milk was affected by material (milk) and curd formation. The low values of water content with high activity of LAB were agreed with results from Bahobail et al, (2014), higher bacterial load effected to high produce acids in the medium attributed to lower water content values and 
increased of total solids from $11.08 \%$ in fermented camel milk and $11.5 \%$ for fresh camel milk.

\section{Ash content}

Different starters have significant difference $(p<0.05)$ on ash content (Table 1). The lower of water content was affecting to higher of ash content. Starter 11 had high of ash content $0.76 \pm 0.04$, and as Owiah et al. (2017) noted that high ash content indicated high inorganic content. Ash content was one of total solid that effected by activity of starters. According to the connection observed by Bibiana et al. (2014), ash content of yoghurt ranged from $0.41 \%$ to $1.02 \%$, yoghurt with higher of ash content indicated that yoghurt was better source of minerals. Ladokun and Oni (2014) stated that mineral compositions of milk could be measure with ash content analysis.

\section{Fat content}

Different starters had significant difference $(\mathrm{p}<0.05)$ on fat content (Table 1). Fat content of starter 41 was higher $(2.37 \pm 0.18)$ and lower of starter $21(1.03 \pm 0.45)$. Fat content had negative correlation with water content. Starter 21 had lower of fat content while water content was higher. Higher of fat content of starter 41 because during fermentation, starter had ability to produce lipase, then lipase degrade fat to fatty acid and glycerol and effected to increase fat in fermented goat milk. LAB had metabolic activities such as breaking down lipids and other compounds. Different results were observed by Bahobail et al. (2014), fermented milk had fat 4.1\%. Different results also reported by Widodo et al. (2013), fermented goat milk with collaboration between ST and LB was $5.40 \pm$
0.28, LA (4.50 \pm 0.99$)$, and LC $5.20 \pm 0.00$. Different results were caused difference in chemical composition of milk, starter cultures that used in fermentation, microbial population, and incubation period.

Fat content was included total solid on milk, as carried out in the study of Ehirim and Onyeneke (2013), improving the consistency of yoghurt was one important role of fat content. Kalyankar et al. (2016) noted that goat milk was higher fat content than cow milk because goat milk contained several hundred fatty acids that different with cow milk.

\section{Syneresis}

Whey separation (wheying-off) means the expulsion of whey from the network on products, then becomes visible as surface whey (Lee and Lucey, 2010). Different starters have significant difference $(\mathrm{p}<0.05)$ on syneresis (Table 1). Syneresis on starter 21 was higher $(29.47 \pm 1.75)$. Starters with low of syneresis were starter $11(23.04 \pm 0.77)$ and starter $41(23.39 \pm 2.39)$. The phenomenon of syneresis in this experiment was higher than that reported by Joon et al. (2017) who observed that yoghurts from goat milk had syneresis (9.92 \pm 0.02$)$, different results between experiment and literature because in this experiment not used stabilizer that effected to increasing syneresis.

Syneresis had negative correlation with viscosity. When fermented goat milk had low syneresis, it had high viscosity. Starter 11 and 41 were lower of syneresis because higher activity of starters, then total solid was increased, increasing of total solid effected to decrease syneresis. The mecanism of starter to decrease syneresis was when starter was added 
in fermented milk, starter can increase total solid that caused by higher density and lower pore size in the protein matrix of the fermented milk gel. Vareltzis et al. (2015) stated that this led to a reduction in syneresis and improvement of the water holding capacity of the gel. Lower syneresis of starters 11 and 41 showed acceptable product by consumers. Higher syneresis of fermented goat milk when adding with starter 21 because separation of liquid from shrinkage gel. Chye et al. (2012) noted that the gel interaction network is weakened and eventually ruptured which reduced the water holding capacity of fermented milk structure.

\section{Viscosity}

Different starters have significant difference $(\mathrm{p}<0.05)$ in viscosity (Table 1). Starters with high viscosity were starter $41(158.67 \pm 2.46)$ and starter $11(154.33 \pm 6.99)$. Additionally, lower viscosity was starter $21(72.50 \pm 0.58)$. Viscosity had correlation with water content and syneresis. Starter 21 had higher water content while lower viscosity and higher syneresis. Similar results were observed by Joon et al. (2017), they reported that yoghurt from goat milk had a softer consistency and lower viscosity than from cow milk. Viscosity was depended on dry matter (Dinkov et al., 2008). Moyane and Afam (2013) noted that sample with lowest viscosity is recorded as lowest consumer acceptance on texture and smoothness sensory attributes.

Table 1. Physicochemical Fermented Goat Milk

\begin{tabular}{cccccc}
\hline $\begin{array}{c}\text { Treatments } \\
\text { (different starters) }\end{array}$ & $\begin{array}{c}\text { Water content } \\
(\%)\end{array}$ & $\begin{array}{c}\text { Ash content } \\
(\%)\end{array}$ & $\begin{array}{c}\text { Fat content } \\
(\%)\end{array}$ & Viscosity $(\mathrm{cP})$ & $\begin{array}{c}\text { Syneresis } \\
(\%)\end{array}$ \\
\hline Starter 11 & $90.48 \pm 0.33^{\mathrm{b}}$ & $0.76 \pm 0.04^{\mathrm{a}}$ & $1.92 \pm 0.49^{\mathrm{ab}}$ & $154.33 \pm 6.99^{\mathrm{a}}$ & $23.04 \pm 0.77^{\mathrm{b} 2}$ \\
Starter 21 & $91.21 \pm 0.08^{\mathrm{a}}$ & $0.70 \pm 0.05^{\mathrm{ab}}$ & $1.03 \pm 0.45^{\mathrm{b}}$ & $72.500 \pm 0.58^{\mathrm{c}}$ & $29.47 \pm 1.75^{\mathrm{a}}$ \\
Starter 25 & $90.89 \pm 0.09^{\mathrm{ab}}$ & $0.74 \pm 0.03^{\mathrm{a}}$ & $1.06 \pm 0.44^{\mathrm{b}}$ & $125.00 \pm 4.04^{\mathrm{b}}$ & $26.52 \pm 0.93^{\mathrm{ab}}$ \\
Starter 29 & $91.05 \pm 0.06^{\mathrm{ab}}$ & $0.71 \pm 0.03^{\mathrm{ab}}$ & $1.12 \pm 0.07^{\mathrm{b}}$ & $113.67 \pm 1.20^{\mathrm{b}}$ & $27.21 \pm 1.19^{\mathrm{ab}}$ \\
Starter 41 & $90.72 \pm 0.21^{\mathrm{ab}}$ & $0.59 \pm 0.04^{\mathrm{b}}$ & $2.37 \pm 0.18^{\mathrm{a}}$ & $158.67 \pm 2.46^{\mathrm{a}}$ & $23.39 \pm 2.39^{\mathrm{b}}$ \\
\hline
\end{tabular}

Remarks : ${ }^{a, b}$ Mean values within a same column followed by the different letters are significantly different at $(p<0.05)$

\section{Conclusion}

It could be concluded that starters 11 and 41 were the best starter that can be applied in fermented goat milk product based on physical quality with lower syneresis and higher viscosity. However, based on chemical quality, starter 11 was the best starter with lower water content and higher ash content.

\section{REFERENCES}

Akabanda, F., Owusu-Kwarteng, J., TanoDebrah, K., Parkouda, C., \& Jespersen, L. (2014). The use of lactic acid bacteria starter culture in the production of nunu, a spontaneously fermented milk product in ghana. International Journal of Food Science,2014,1-11. https://doi.org/10.1155/2014/721067

\section{Acknowledgment}

I would thank to NPUST, Taiwan because NPUST give me opportunity to study and funding my experiments. 
Alyaqoubi, S., Abdullah, A., Samudi, M., Abdullah, N., Addai, Z. R., \& Al-ghazali, M. (2015). Advance journal of food science \& technology: AJFST. Advance Journal of Food Science and Technology, 7(4), 235-241.

AOAC. (2000). Official Methods of Analysis. $17^{\text {th }}$ Edition, Gaithersburg, MD, USA: The Association of Official Analytical Chemists.

Bahobail, A. S., Ali, A. A., \& Alyan, A. A. (2014). Effect of fermentation process on the improvement of nutrition value of camel milk. International Journal of Multidisciplinary \& Current Research, 2, 78-82. Retrieved from http://ijmcr.com

Bibiana, I., Joseph, S., \& Julius, A. (2014). Physicochemical, microbiological \& sensory evaluation of yoghurt sold in Makurdi metropolis. African Journal of Food Science \& Technology, 5(6), 129135. Retrieved from http://www.interesjournals.org/ajfst/june2014-vol-5-issue-6/physicochemicalmicrobiological-and-sensory-evaluationof-yoghurt-sold-in-makurdi-metropolis

Chye, S. J., Ahmad, R., \& Noorr Azizah, A. A. (2012). Studies on the physicochemical \& sensory characteristics of goat's milk dadih incorporated with tropical- fruit purees. International Food Research Journal, 19(4), 1387-1392. Retrieved from http://www.ifrj.upm.edu.my
Dinkov, K., Duskova, M., \& Toskhov, N. (2008). Regression models for density \& viscosity of ultrafiltration milk concentrates BulgarianJournal of Agricultural Science, 14(6), 542-548.

Ehirim, F. N., \& Onyeneke, E. N. (2013). Physico - Chemical \& organoleptic properties of yoghurt manufactured with cow milk \& goat milk. Natural \& Applied Sciences, 4(4), 245-252.

Elida, M. (2002). profil bakteri asam laktat dari dadih yang difermentasi dalam berbagai jenis bambu \& potensinya sebagai probiotik. Master Thesis. Bogor: Program Studi Ilmu Pangan, Institut Pertanian Bogor.

Hadisaputro, W., Taufiq, T. T., \& Anindita, N. S. (2013). Fermented goat milk \& cow milk produced by different starters of lactic acid bacteria: Quality Studies. Journal of Agricultural Science \& Technology, 3, 904-911.

Joon, R., Mishra, S. K., Brar, G. S., Singh, P. K., \& Panwar H. (2017). Instrumental texture $\&$ syneresis analysis of yoghurt prepared from goat \& cow milk. The Pharma Innovation Journal, 6(7), 971-974. Retrieved from http://www.thepharmajournal.com/archive s/2017/vol6issue7/PartG/6-7-73-280.pdf

Kalyankar, S. D., Khedkar, C. D., \& Patil, A. M. (2016). Goat: Milk. In Encyclopedia of Food \& Health (pp. 256-260). London: Elsevier. https://doi.org/10.1016/B978-0-12384947-2.00358-5 
Ladokun, O., \& Oni, S. (2014). Fermented milk products from different milk types. Food \& Nutrition Sciences, 5(13), 1228-1233. https://doi.org/10.4236/fns.2014.513133

Lawal, A. K., \& Adedeji, O. M. (2013). Nutritional and elemental analysis of warankasi (fermented milk product) sold in Lagos metropolis. International Research Journal of Biotechnology, 4(6), 112-116.

Lee, W. J., \& Lucey, J. A. (2010). Formation \& physical properties of yogurt. J. Anim. Sci, 23(9), 1127-1136.

Moyane, J. N., \& Jideani, A. I. O. (2013). The physicochemical \& sensory evaluation of commercial sour milk (amasi) products. African Journal of Food Science, 7(4), 56-62.

https://doi.org/10.5897/AJFS12.089

Nouri, M., Ezzatpanah, H., \& Abbasi, S. (2011). Application of renneted skim milk as a fat mimetics in nonfat yoghurt. Food \& Nutrition Sciences, 2(6), 541-548. https://doi.org/10.4236/fns.2011.26077

Nuraida, L. (2015). A review: Health promoting lactic acid bacteria in traditional Indonesian fermented foods. Food Science and Human Wellness, 4(2), 47-55. https://doi.org/10.1016/J.FSHW.2015.06.001
Owiah, S. G., Naomi, D., Vida, G., \& Martha, A. (2016). Preparation of semi-dairy yoghurt from soy bean. American Journal of Food Science \& Technology, Vol. 5, 2016, Pages 1-5, 5(1), 1-5. https://doi.org/10.12691/AJFST-5-1-1

Surono, I. S. (2003). In vitro probiotic properties of indigenous dadih lactic acid bacteria. Asian-Australasian Journal of Animal Sciences, 16(5), 726-731. https://doi.org/10.5713/ajas.2003.726

Syukur, S., Hermansyah, A., \& Fachrial, E. (2016). Probiotics \& strong antimicrobial of buffalo milk fermentation (dadih) from different places in west sumatera indonesia. Research Journal of Pharmaceutical, Biological \& Chemical Sciences, 7(6), 386-392.

Vareltzis, P., Adamopoulos, K., Stavrakakis, E., Stefanakis, A., \& Goula, A. M. (2016). Approaches to minimise yoghurt syneresis in simulated tzatziki sauce preparation. International Journal of Dairy Technology, 69(2), 191-199. https://doi.org/10.1111/1471-0307.12238

Wang, D. H. and H. C. Tsai. 2015. Bamboo resources $\&$ carbon storage in Taiwan. $10^{\text {th }}$ World Bamboo Congress, Korea. 
Widyastuti, Y., Rohmatussolihat, \& Febrisiantosa, A. (2014). The role of lactic acid bacteria in milk fermentation. Food \& Nutrition Sciences, 5(4), 435-442. https://doi.org/10.4236/fns.2014.54051
Yelnetty, A., Purnomo, H., . P., \& Mirah, A. (2011). Biochemical characteristics of lactic acid bacteria with proteolytic activity \& capability as starter culture isolated from spontaneous fermented local goat milk Journal of Natural Sciences Research, 4(10), 137-146. 